УДК 378.045.2

(C) Кабанська Г. А., Кабанська О. С., Мельникова О. В., 2021

https://orcid.org/0000-0002-0308-7215

https://orcid.org/0000-0002-4775-1990

https://orcid.org/0000-0002-6807-8440

DOI: $10.34142 / 23128046.2021 .51 .09$

\author{
Г. А. Кабанська, \\ О. С. Кабанська, \\ О. В. Мельникова
}

\title{
ПЕДАГОГІЧНА ПРАКТИКА У ЗАКЛАДАХ ЗАГАЛЬНОЇ ОСВІТИ - ПРОСТІР ФОРМУВАННЯ ПРОФЕСІЙНИХ КОМПЕТЕНТНОСТЕЙ МАЙБУТНЬОГО ВЧИТЕЛЯ
}

У статті автори розкрили важливі аспекти педагогічної практики у закладах повної загальної освіти в системі підготовки майбутнього вчителя відповідно вимог освітнього ступеня «бакалавр». 3 опорою на особистісний $i$ компетентнісний підходи проаналізовано иілі, завдання, зміст програми такої педагогічної практики.

Наголошено увагу на значенні педагогічної практики для систематизації $i$ апробачії набутих знань і фахових компетентностей. Зміст модулів робочої навчальної програми побудовано таким чином, щзо кожен здобувач може реалізувати свою персональну освітню траєкторію, набути досвіду самостійного проведення навчально-виховної роботи учнівським колективом та окремими учнями закладу загальної середньої освіти. Відкритість і прозорість контрольних заходів, діагностичний $i$ формувальний аспект оцінювання $\epsilon$ вагомим стимулом для студентів до професійного самовдосконалення, педагогічної творчості та науково-дослідницької роботи ще на етапі здобуття вищої освіти.

Авторами статті багато уваги приділено ресурсам педагогічної практики щодо розвитку активного мислення на основі сучасних наукових досягнень. Для иъого передбачено елементи колаборації із структурними підрозділами закладів освіти, співпрацю $з$ викладачами університету $i$ вчителями-методистами, елементи взаємного навчання, групові освітні проєкти.

Акцентовано увагу, що під час підготовки і звітування про результати проходження педагогічної практики студенти демонструють рівень осмислення теоретичних знань, одержаних при вивченні спеціальних та психолого-педагогічних дисииплін, досвід практичної педагогічної діяльності в реальних умовах. Важливим мотиваиійним моментом у статті визначено процедуру знайомства студентів із закладом, де проходитиме практика, вчителями-методистами, сучасним станом навчально-виховної роботи у школі, 3 передовим педагогічним досвідом. Викладачі університету системно забезпечують індивідуальну підтримку, менторський супровід $i$ психолого- 
педагогічну, методичну допомогу студентам-практикантам у розв 'язанні задач навчання та виховання учнів.

Особливо иікавими для студентів є завдання, пов'язані з навчальною взаємодією з учнями, вивчення їх індивідуальних та вікових особливостей.

Авторами зроблено висновок про те, щзо педагогічна практика сприяє формуванню у студентів творчого, дослідницького підходу до педагогічної діяльності, дає змогу набути досвіду аналізу підсумків своєї навчальнопізнавальної $i$ дослідницької діяльності за період навчання в університеті, мотивує до самоосвіти, формує критичне мислення, актуалізує потребу вивчення досвіду роботи вчителів з предметної галузі.

Ключові слова: бакалаврат, компетентнісний підхід, педагогічна практика, студент, університет, освіта, особистість, якість освіти.

Kabanska H. A., Kabanska O. A., Melnykova O. V. Pedagogical practice in general education institutions - space of formation of professional competencies of the future teacher. In the article, the authors revealed important aspects of pedagogical practice in institutions of complete general education in the system of training future teachers of economic disciplines in accordance with the requirements of the educational degree "bachelor". Based on personal and competence approaches, the goals, objectives, and content of the program of such pedagogical practice are analyzed.

The article emphasizes the importance of pedagogical practice for the systematization and testing of acquired knowledge and professional competencies. The content of the modules of the working curriculum is built in such a way that each applicant can implement their personal educational trajectory, gain experience in conducting educational work independently by the student body and individual students of general secondary education.

Openness and transparency of control measures, diagnostic and formative aspect of assessment are an incentive for students to professional self-improvement, pedagogical creativity and research work at the stage of higher education.

The authors of the article pay much attention to the resources of pedagogical practice for the development of active economic thinking on the basis of modern achievements of economics. For this purpose, elements of collaboration with structural subdivisions of educational institutions, cooperation with university teachers and teachers-methodologists, elements of mutual learning, group educational projects are provided.

Emphasis is placed on the fact that during the preparation and reporting on the results of pedagogical practice, students demonstrate the level of understanding of theoretical knowledge obtained in the study of special and psychological-pedagogical disciplines, experience of practical pedagogical activities in real conditions. An important motivational point in the article is the procedure of acquaintance of students with the institution where the practice will take place, teachers-methodologists, the current state of educational work at school, with advanced pedagogical experience. University teachers systematically provide individual support, mentoring and 
psychological and pedagogical, methodological assistance to students-interns in solving problems of teaching and educating students.

Of particular interest to students are the tasks associated with educational interaction with students, the study of their individual and age characteristics.

The authors conclude that pedagogical practice promotes the formation of students' creative, research approach to teaching, allows them to gain experience in analyzing the results of their educational and research activities during their studies at the university, motivates self-education, forms critical thinking, actualizes the need study of the experience of teachers in the subject area.

Keywords: bachelor, competence approach, pedagogical practice, student, university, education, personality, quality of education.

Вступ. Сьогодення системи вищої освіти в Україні переживає серйозні трансформаційні процеси. Зміни, обумовлені прогресуванням наук і технологій, динамікою і контраверсією суспільних і культурних процесів, торкнулися усіх елементів підготовки фахівців у галузі соціальних, поведінкових наук. Наша країна долучилася до країн-членів ООН у своєму прагненні глобального процесу забезпечення сталого розвитку (Pro zatverdzhennia Kontseptsii rozvytku pedahohichnoi osvity, 2018; Tsili staloho rozvytku ta Ukraina, 2021). Програми, які розроблені професорсько-викладацьким колективом Харківського національного педагогічного університету імені Г. С. Сковороди, за активної участі представників студентства, широких груп стейголдерів контекстно спираються на ключові позиції програми національного розвитку, спрямовані на формування професійних вмотивованих, відкритих інноваціям компетентних фахівців. Такі фахівці здатні розв'язувати складні спеціалізовані задачі та практичні проблеми в ситуації змін і невизначеності.

Мета та завдання. Метою цієї публікації визначено конкретизувати пріоритетні аспекти організації педагогічної практики у закладах повної загальної освіти в системі підготовки майбутнього вчителя на прикладі Харківського національного педагогічного університету імені Г.С. Сковороди відповідно вимог освітнього ступеня «бакалавр». 3 опорою на особистісний $\mathrm{i}$ компетентнісний підходи ця мета деталізована у таких завданнях: проаналізувати цілі, завдання, охарактеризувати зміст програми такої педагогічної практики.

Методи дослідження. Після визначення теми, мети, завдань дослідження було використано метод системного i порівняльного аналізу освітньопрофесійних програм, навчальних програм педагогічної практики, звітної документації, навчально-методичного забезпечення освітнього процесу у Харківському національному педагогічному університеті імені Г. С. Сковороди. На підставі отриманих аналітичних матеріалів здійснено узагальнення i розроблено заходи 3 проєктування конструктивних оновлень програми $\mathrm{i}$ навчально-методичного контенту педагогічної практики в умовах прогресування формату змішаного навчання в університеті. 
Результати. Дослідженням встановлено, що освітній компонент педагогічної практики в закладах загальної середньої освіти у програмі підготовки здобувачів першого (бакалаврського) рівня вищої освіти забезпечує системність, інтеграцію, інтерактивність освітнього процесу (VorozhbitHorbatiuk, Melnykova \& Kabanska, 2021; Ievtukh, 2019). Проаналізований навчально-методичний контент освітньої компоненти підтверджує факт реалізації в системі підготовки вчителів основних положень комплексного підходу до здійснення діяльності в професійній сфері та реалізує це через навчання та практичну підготовку (Rekomendatsii pro provedennia praktyky studentiv vyshchykh navchalnykh zakladiv Ukrainy, 2013). Освітня компонента педагогічної практики містить модулі, орієнтовані на актуальні напрями розвитку психолого-педагогічної науки. Досвід і програмні результати, здобуті під час проходження педагогічної практики розкривають перспективи подальшої професійної та наукової кар'єри здобувачів першого (бакалаврського) рівня освіти. Під час виконання завдань педагогічної практики здобувачі систематизують знання з фахових дисциплін, вчаться ефективно організовувати освітній простір, проводити навчальні заняття, організовувати співпрацю учнів на засадах партнерства.

Варто відмітити цінний досвід орієнтування контрольних і діагностичних заходів під час організації педагогічної практики на цілі сталого розвитку, що передбачає виконання завдань зі збору емпіричних матеріалів щодо аналізу розвитку підприємств, організацій, установ, забезпечення їх фінансовоекономічної стабільності, конкурентоспроможності (Osvitno-profesiini prohramy pidhotovky zdobuvachiv pershoho (bakalavrskoho) rivnia vyshchoi osvity KhNPU imeni H.S. Skovorody, 2019). Ресурси педагогічної практики мають елементи, корисні для особистісного і професійного зростання майбутніх учителів.

На підставі аналізу матеріалів з обраної теми (Osvitno-profesiini prohramy pidhotovky zdobuvachiv pershoho (bakalavrskoho) rivnia vyshchoi osvity KhNPU imeni H.S. Skovorody, 2019) зазначимо, що метою педагогічної практики у закладах повної загальної освіти $\epsilon$ набуття професійних якостей майбутнього вчителя відповідно вимог освітнього ступеня «бакалавр»; розвиток у студентів умінь і навичок самостійного проведення навчально-виховної роботи учнівським колективом та окремими учнями; спонукання студентів до професійного самовдосконалення, педагогічної творчості та науково-дослідницької роботи; розвиток активного економічного мислення на основі сучасних досягнень економічної науки (Osvitno-profesiini prohramy pidhotovky zdobuvachiv pershoho (bakalavrskoho) rivnia vyshchoi osvity KhNPU imeni H.S. Skovorody, 2019).

Через призму компетентнісного підходу можна визначити основні завдання педагогічної практики у закладах повної загальної середньої, спеціалізованої та професійної освіти: поглиблення та закріплення теоретичних знань, одержаних при вивченні спеціальних та психолого-педагогічних дисциплін із практикою, формування вмінь та навичок педагогічної праці; знайомство студентів із сучасним станом навчально-виховної роботи у школі, 3 
передовим педагогічним досвідом, здійснення допомоги з боку студентів у розв'язанні задач навчання та виховання учнів.

У реаліях сьогодення важливим аспектом проходження педагогічної практики майбутніми фахівцями є організація взаємодії та спілкування студентів 3 учнями відповідно до особистісно зорієнтованого підходу, з опорою на педагогіку партнерства.

Безсумнівно значимим є вивчення індивідуальних та вікових особливостей здобувачів загальної освіти.

У межах реалізації освітньої компоненти вартісним $є$ можливість формування соціально значимих так званих гнучких навичок: формування у студентів творчого, інноваційного підходу до педагогічної діяльності, надбання ними навичок аналізу підсумків своєї праці, формування потреби в самоосвіті; формування критичного підходу щодо вивчення передового педагогічного досвіду роботи вчителів 3 предмету та класних керівників; знайомство 3 актуальними технологіями навчання.

Наприклад, у результаті проходження педагогічної практики здобувачі першого (бакалаврського) рівня з економічних дисциплін досягають очікуваних результатів навчання: демонструвати стійке розуміння принципів економічної науки, особливостей функціонування економічних систем; використовувати професійну аргументацію для донесення інформації, ідей, проблем та способів їх вирішення до фахівців і нефахівців у сфері економічної діяльності; пояснювати моделі соціально-економічних явищ 3 погляду фундаментальних принципів і знань на основі розуміння основних напрямів розвитку економічної науки; застосовувати відповідні економіко-математичні методи та моделі для вирішення економічних задач; застосовувати набуті теоретичні знання для розв'язання практичних завдань та змістовно інтерпретувати отримані результати; планувати можливості особистого професійного розвитку; працювати самостійно, виявляти ініціативу та підприємливість, бути критичним і самокритичним; демонструвати здатність діяти соціально відповідально та свідомо на основі етичних мотивів, поваги до різноманіття думок, індивідуальних та міжкультурних відмінностей людей.

Педагогічна практика у змістовій частині передбачає послідовні модулі: 1. Організаційно-звітна робота. 2. Навчально-методична робота. 3. Виховна робота (Kafedra osvitolohii ta innovatsiinoi pedahohiky KhNPU imeni H. S. Skovorody, 2021).

Обговорення. Наголосимо тут, що процесуально проходження педагогічної практики передбачає моделювання професійних ситуацій, мотивування здобувачів до прояву педагогічної ініціативи, відкритість інноваціям. Сильними мотиваційними ресурсами визначено використання на етапі організації роботи настановної і підсумкової конференції випускників, магістрантів, практикуючих фахівців у галузі педагогічної освіти.

Склалися цікаві традиції ознайомлення здобувачів із програмою практики, iii метою та завданнями: розкриття прав і обов'язків практиканта; визначення термінів і порядку організації практики; узгодження графіків консультацій; 
складання індивідуальних завдань. Серед таких традицій варто виокремити: експрес-опитування здобувачів напередодні проходження практики «Мої очікування від педагогічної практики», воркшоп «Дисципліни в сучасній школі: нетворкінг». Розміщення програми практики і визначених контрольних точок на освітній платформі MOODLE.

Знайомство 3 навчальним закладом та його керівництвом відбувається в робочому режимі, оскільки студент патронується вчителем закладу освіти - бази проходження практики ще напередодні формування програми.

На цьому етапі ключовою системною задачею $\epsilon$ : формування партнерства i співпраці між учителем, практикантом і методистами; розроблення i узгодження плану роботи студента-практиканта 3 планом виховної роботи класного керівника; складання індивідуального плану роботи разом 3 методистом практики; визначення порядку та строків виконання завдань практики.

В умовах провадження карантинних заходів, використання елементів змішаного навчання, відвідання студентом-практикантом необхідних консультацій з питань практики, які проводять керівники - методисти від профільних кафедр, часто відбувається із використанням цифрових застосунків. Синхронно: відео конференції, чат в мобільному застосунку, онлайн зустріч на платформі ZOOM, MEET. Асинхронно: програма виконання завдань модулів на освітній платформі MOODLE, обговорення i консультування викладачів психолого-педагогічних дисциплін із використанням інтерактивних дошок, Kahoot, Padlet. Особливо здобувачами поціновуються елементи мікро-навчання і мобільного навчання, коли завдання деталізуються, формуються у відносно завершені модулі, і здобувач самостійно використовує їх за потребою. Це, традиційно, педагогічні пам'ятки, рекомендації до ведення педагогічного щоденника спостережень, фіксація різних видів організаційної, навчальнометодичної, виховної та звітної робіт, правила і шаблони оформлення звітної документації.

3 використанням цифрових сервісів відбувається і представлення звітної документації керівнику практики. Підготовка виступу за наслідками педагогічної практики на підсумкову конференцію передбачає підготовку презентацій, написання есе, оформлення стендової доповіді тощо. Захист звіту та отримання підсумкової оцінки (іспиту) передбачає використання елементів формувального і взаємного оцінювання. Здобувачі часто проявляють ініціативу до самооцінювання проходження педагогічної практики за критеріями i показниками самоаналізу роботи вчителя, у формах самоаналізу уроків (Kafedra osvitolohii ta innovatsiinoi pedahohiky KhNPU imeni H.S. Skovorody, 2021).

Партнерство в дії передбачає обговорення результатів практики та розробку рекомендацій щодо удосконалення практичної підготовки від здобувачів, які пройшли педагогічну практику успішно.

Апріорно важливим є етап вивчення специфіки організації навчального процесу в школі та коледжі, особливостей викладання різних дисциплін: профіль, науково-методична проблема, над якою працює заклад, ознайомлення 3 
навчальною програмою, аналіз програм, планів. Корисні ресурси з 2020 року у цьому аспекті презентовано завдяки реєстрації закладів освіти на платформі HUMAN. У зручному режимі за заздалегідь сформованим планом із шаблоном аналізу студенти відвідують уроки вчителів із предметів за профілем. Практична робота досить розмаїта.

Це i підготовка планів-конспектів уроків, навчально-методичного забезпечення. Розробка i виготовлення наочності до залікових уроків здійснюється контекстно, 3 урахуванням сфери пізнавальних інтересів здобувачів. Проведення і самоаналіз пробного уроку, залікового уроку. відвідання залікових уроків студентів-практикантів, індивідуальна робота 3 учнями, організація консультацій та додаткових занять, участь у засіданнях предметних та методичних комісій, педагогічної ради школи - неповний перелік активностей студентів-практикантів. Така широка практична педагогічна діяльність сприяє професійній ідентифікації і самовизначенню.

Відкритість, чіткість і прозорість контрольних заходів, діагностичний інструментарій, формувальний аспект оцінювання в сучасних умовах роботи закладів загальної освіти - це спільні освітні проєкти, до яких долучаються здобувачі вищої освіти.

Ознайомлення і практикування позакласної виховної діяльності передбачає долучення здобувачів до роботи шкільних клубів, гуртків, театру, студій, художніх івентів.

Завжди особливо ретельно здобувачі готують матеріали з розроблення анкет із метою визначення інтересів учнів, анкетування учнів та подальший аналіз отриманих результатів, складання психолого-педагогічної характеристики класу.

Оцінювання результатів проходження педагогічної практики передбачає висвітлення поточних i підсумкових якісних характеристик у відзиві 3 рекомендованою оцінкою за проходження практики, завірена директором школи, підписана вчителем-предметником, класним керівником та характеристика від керівника практики від університету. До цього документу додається звіт про педагогічну практику у довільній формі на основі індивідуального плану і щоденника із самооцінюванням, індивідуальний план роботи студента-практиканта, підписаний методистами з предмету, щоденник практики, підписаний студентом-практикантом, методистом 3 предмету i методистом з педагогічних дисциплін.

Новацією останніх років стала підготовка здобувачами тез виступу та презентація на підсумкову конференцію, які містять аналіз проведеної роботи із вказівками своїх досягнень, недоліків, особистих вражень і пропозицій до подальшого удосконалення педагогічної підготовки студентів.

Висновки. Підсумовуючи викладене вище, зазначимо, що підготовка i звітування про результати проходження педагогічної практики дає важливі ресурси професійного самовизначення здобувачів, які набувають досвіду практичної педагогічної діяльності в реальних умовах. Важливим мотиваційним моментом у статті виокремлено знайомство студентів із закладом, де 
проходитиме практика, вчителями-методистами, сучасним станом навчальновиховної роботи у школі, аналіз педагогічного досвіду. Викладачі університету системно забезпечують індивідуальну підтримку в реалізації освітньої траєкторії кожного здобувача, використовують при консультуванні широкий спектр методичних, організаційних засобів, цифрових сервісів і застосунків. 3 огляду на реалії сьогодення перспективою подальшої розробки заявленої теми визначено питання колаборації ОТГ і університету, закладів загальної середньої освіти, розширення спектру закладів і установ - баз проходження практики, залучення адміністрації цих закладів в якості стейголдерів освітньо-професійних програм підготовки здобувачів у Харківському національному педагогічному університеті імені Г.С. Сковороди.

\section{ЛІТЕРАТУРА:}

Ворожбіт-Горбатюк В., Мельникова О., Кабанська А. Науково-педагогічна практика здобувачів другого магістерського рівня вищої освіти, спеціальність 051 Економіка: досвід ХНПУ імені Г.С. Сковороди. Молодь і ринок, №4/190. 2021. С. 17-21.

Євтух М.Б. Роль педагогічної практики у підготовці майбутнього вчителя. Scientific discoveries: projects, strategies and development: Collection of scientific papers $\langle\Lambda \mathrm{O} Г О \Sigma$ » with Proceedings of the International Scientific and Practical Conference (Vol. 2), October 25, 2020 p., № 69, T. 2. 61 2019. Edinburgh, UK: European Scientific Platform. C. 140-143.

Про затвердження Концепції розвитку педагогічної освіти : Наказ Міністерства освіти і науки України від 16.07.2018 № 776. URL: https:// mon.gov.ua/ua/npa/prozatverdzhennyakoncepciyi-rozvitku-pedagogichnoyi-osviti

Рекомендації про проведення практики студентів вищих навчальних закладів України. К. : Державна наукова установа «Інститут інноваційних технологій і змісту освіти», 2013. $27 \mathrm{c}$.

Кафедра освітології та інноваційної педагогіки ХНПУ імені Г.С. Сковороди (2021). URL : https://www.kaf-pedagogy-hnpu.com/

Цілі сталого розвитку та Україна (2021). URL : https://www.kmu.gov.ua/diyalnist/cili-stalogorozvitku-ta-ukrayina

Освітньо-професійні програми підготовки здобувачів першого (бакалаврського) рівня вищої освіти ХНПУ імені Г.С. Сковороди (2019). URL : http://smc.hnpu.edu.ua/files/Osvitni_programi/Osvitni_programu_bakalavr/2019_rik/Ekono mika.pdf

\section{REFERENCES:}

Ievtukh, M.B. (2019). Rol pedahohichnoi praktyky u pidhotovtsi maibutnoho vchytelia. [The role of pedagogical practice in the training of future teachers] Scientific discoveries: projects, strategies and development: Collection of scientific papers $\langle\Lambda \mathrm{O} О Г \mathrm{O} \Sigma$ » with Proceedings of the International Scientific and Practical Conference (Vol. 2), October 25, 2020 p., № 69, T. 2. 61. Edinburgh, UK: European Scientific Platform. C. 140-143. (in Ukrainian).

Kafedra osvitolohii ta innovatsiinoi pedahohiky KhNPU imeni H.S. Skovorody (2021) [Education and Innovative Pedagogy Department, Kharkiv Hryhoriy Skovoroda National Pedagogical University]. URL : https://www.kaf-pedagogy-hnpu.com/ (in Ukrainian).

Osvitno-profesiini prohramy pidhotovky zdobuvachiv pershoho (bakalavrskoho) rivnia vyshchoi osvity KhNPU imeni H.S. Skovorody (2019). [Educational and professional training programs for applicants for the first (bachelor's) level of higher education of KhNPU named $\begin{array}{lllll}\text { after GS } & \text { Frying } & \text { pans] }\end{array}$ http://smc.hnpu.edu.ua/files/Osvitni_programi/Osvitni_programu_bakalavr/2019_rik/Ekono mika.pdf (in Ukrainian). 
Pro zatverdzhennia Kontseptsii rozvytku pedahohichnoi osvity (2018). [On approval of the Concept of development of pedagogical education] : Nakaz Ministerstva osvity i nauky Ukrainy vid 16.07.2018 № 776. URL: https:// mon.gov.ua/ua/npa/pro-zatverdzhennyakoncepciyirozvitku-pedagogichnoyi-osviti (in Ukrainian).

Rekomendatsii pro provedennia praktyky studentiv vyshchykh navchalnykh zakladiv Ukrainy (2013). [Recommendations on the practice of students of higher educational institutions of Ukraine]. Kyiv : Derzhavna naukova ustanova «Instytut innovatsiinykh tekhnolohii i zmistu osvity», 27 s. (in Ukrainian).

Tsili staloho rozvytku ta Ukraina (2021). [Sustainable Development Goals and Ukraine] URL : https://www.kmu.gov.ua/diyalnist/cili-stalogo-rozvitku-ta-ukrayina (in Ukrainian).

Vorozhbit-Horbatiuk, V., Melnykova, O. \& Kabanska, H. (2021). Naukovo-pedahohichna praktyka zdobuvachiv druhoho mahisterskoho rivnia vyshchoi osvity, spetsialnist 051 Ekonomika: dosvid KhNPU imeni H.S. Skovorody. [Scientific and pedagogical practice of applicants for the second master's level of higher education, specialty 051 Economics: the experience of KhNPU named after GS Frying pans]. Molod i rynok, №4/190. S. 17-21. (in Ukrainian).

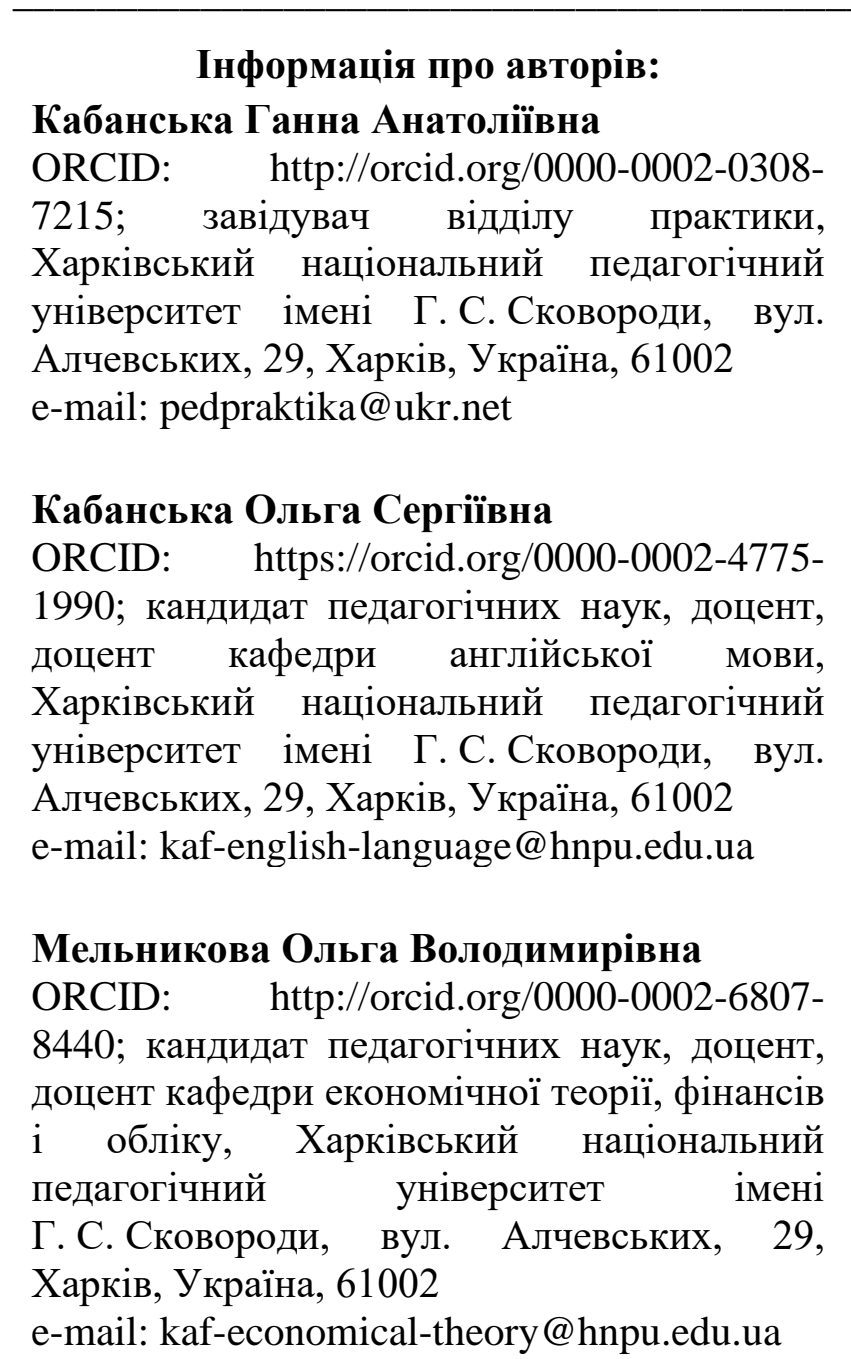

\section{Information about the authors:}

Kabanska Hanna Anatoliivna:

ORCID: http://orcid.org/0000-0002-0308-

7215; Head of the Department of Practice,

H.S. Skovoroda Kharkiv National Pedagogical

University, Kharkiv, Alchevskykh Street, 29,

Kharkiv, Ukraine, 61002

e-mail: pedpraktika@ukr.net

\section{Kabanska Olha Serhiivna:}

ORCID: https://orcid.org/0000-0002-4775-

1990, PhD, Associate Professor, Associate Professor of the Department of English Language, H. S. Skovoroda Kharkiv National Pedagogical University, Alchevskykh Street, 29, Kharkiv, Ukraine, 61002

e-mail: kaf-english-language@hnpu.edu.ua

\section{Melnykova Olha Volodymyrivna:}

ORCID: https://orcid.org/0000-0002-68078440; Ph.D. (Pedagogy), Associate Professor, Associate Professor of the Economic Theory, Finance and Accounting Department, H. S. Skovoroda Kharkiv National Pedagogical University, Alchevskykh Street, 29, Kharkiv, Ukraine, 61002

e-mail: kaf-economical-theory@hnpu.edu.ua

Цитуйте цю статтю як: Кабанська Г. А., Кабанська О. С., Мельникова О.В. Педагогічна практика у закладах загальної освіти - простір формування професійних компетентностей майбутнього вчителя. Теорія та методика навчання та виховання. 2021. № 51. C. 88-96. DOI: 10.34142/23128046.2021.51.09 